\title{
Globalization and disease: in an unequal world, unequal health!
}

\author{
Globalização e doença: num mundo \\ desigual, saúde desigual!
}

Paulo Marchiori Buss 1

\footnotetext{
1 Presidência, Fundação Oswaldo Cruz.

Av. Brasil 4365,

Rio de Janeiro, $R$

21045-900, Brasil.
}

\begin{abstract}
In this paper, originally presented at an event held by the National Institutes of Health $(N I H)$ in the United States, the author analyzes the repercussions of globalization on various health aspects: the spread of infectious and parasitic diseases, bioterrorism, and new behavioral patterns in health, among others. He goes on to examine the positive and negative effects of international agreements on health, particularly in the trade area, including the TRIPS Agreement on medicines in the area of public health. The paper concludes that the resumption of cooperation among nations is the best way to achieve world progress in public health.
\end{abstract}

Key words Social Inequity; Commerce; World Health; Globalization

Resumo No presente texto, originalmente apresentado em evento promovido pelos National Institutes of Health, dos Estados Unidos, o autor analisa as repercussões da globalização sobre a saúde em diversos aspectos: a disseminação das doenças infecto-parasitárias, o bioterrorismo, os novos padrões comportamentais em saúde, entre outros. Examina ainda os efeitos positivos e negativos dos acordos entre nações sobre a saúde, particularmente na área do comércio, incluindo o Acordo Trips, sobre os medicamentos na área da saúde pública. Conclui que a retomada da cooperação entre as nações é o melhor caminho para o avanço mundial da saúde pública.

Palavras-chave Iniqüidade Social; Comércio; Saúde Mundial; Globalização 
One of the contemporary world's main characteristics is the extremely unequal distribution of wealth between regions and countries, and among population groups within countries. Such unequal distribution of wealth leads to similar inequality in living and health conditions in a virtually uniform relationship. Thus, the worst living and health conditions occur in the poorest countries and population groups.

This unequal distribution of wealth and poverty has gained momentum with the world development model known as globalization, implemented in the last decade. The main economic characteristics of globalization include: the international division of production and labor; further opening of non-industrialized countries to capital and exports from developed countries (with concomitant restrictions on their own exports to the industrialized markets); an intense flow of financial capital, no longer under the control of the national states, but rather subordinated to the large profit-seeking transnational conglomerates and leading to an unprecedented accumulation of wealth and inequality; and the globalization of severe environmental problems and behavioral patterns in almost every field of human life, such as nutrition, sexuality, reproduction, and interpersonal relations.

The "short twentieth century", a term coined by historian Eric Hobsbawm (1998:22) to describe the last century as it drew to a close, brought an extraordinary "revolution in transportation and communication, which practically wiped out time and distance". This immense approximation between such unequal cultures and economies "made the globe become the basic operational unit, and older units such as 'national economies' defined by the states' territorial policies were reduced to mere 'difficulties' for the transnational activities" (Hobsbawm, 1998:22).

According to a widespread and naïve notion, economic growth per se is a virtuous phenomenon, and the wealth originating from it is equally distributed in society, thus improving quality of life and health for all social strata, particularly the poorest. Yet in reality this is rarely the case.

A recently-published study by the World Bank (2001:39) itself stated that "globalization has helped reduce poverty in a large number of developing countries, but it must be harnessed better to help the world's poorest, most marginalized countries improve the lives of their citizens. This is especially important in the wake of September 11 and the worldwide economic slowdown, which is expected to hit poor people par- ticularly hard". The study also calls on wealthy countries to open their markets to exports from developing countries and to curtail their large agricultural subsidies, which undercut poor countries' exports. The report argues for a substantial increase in development assistance, particularly to address problems in education and health.

In reality, recommendations to open markets - the core of adjustment policies promoted by international agencies like the World Bank and the International Monetary Fund (IMF) have had a disastrous impact on several of the world's economies. According to Joseph Stiglitz, until recently the World Bank's chief economist, the most successful economies in the 1990s China, India, and the United States - explicitly flexibilized the market rules and briskly opposed IMF macroeconomic policies and the principles of the so-called Washington Consensus, which established the basis for the neoliberal movement and globalization (Pettifor, 2000).

Globalization, characterized by an extensive opening of world markets, with liberalization and deregulation of international commerce, frequently destroys thousands of jobs in the new or incipient industries in underdeveloped countries. Without any protection, their industry proves incapable of competing with the First World's highly automated and more efficient industries, which have thus began exporting unemployment to the Third World.

The resulting unemployment in poor countries is an unmistakable source of diseases. Several studies in many parts of the world have correlated unemployment to degraded individual, family, and societal health conditions. Deteriorating nutritional conditions and mental health, along with increasing difficulties in accessing medical care and medicines, are among the obvious causes of unemployment and the worsening overall health situation.

In the financial field, globalization includes speculative assaults by volatile transnational capital (so-called hot money) on Third World currencies, eroding their purchasing capacity. The collapse of local currencies prevents Third World countries from acquiring essential goods like food, medicines, and vaccines on the international market. The Children's Vaccine Initiative (CVI) of the World Health Organization (WHO) has reported that national budgets are deteriorating in the economic crisis caused, to a major extent, by speculative attacks, and that "the cuts in budget to purchase vaccines are inevitable, leading to the interruption of basic immunization programs" (WHO, 1998). The World Health Organization also estimates that some 
four million children die every year (mostly in poor countries) from infectious diseases that are preventable by existing vaccines which in turn are inaccessible due to problems such as those mentioned above in relation to economic globalization.

As defined in a 1992 report by the Institute of Medicine, emerging infectious diseases are the group of diseases that correlate most closely to globalization. They include diseases whose incidence has increased in the last two decades or is predicted to increase in the near future (Lenderberg et al., 1992). Modern demographic and environmental conditions favoring the spread of infectious diseases worldwide include:

- global travel;

- globalization of the food supply and centralized food processing;

- population growth and increased urbanization and crowding;

- population movements due to civil wars, famine, and other manmade or natural disasters;

- irrigation, deforestation, and reforestation projects that alter the habitats of disease vectors and reservoirs;

- human behaviors such as intravenous drug use and unprotected sexual behavior;

- increased use of antimicrobial agents and pesticides, hastening the development of resistance; and

- increased human contact with tropical rainforests and other wilderness habitats that are reservoirs for insects and animals harboring emerging or reemerging infectious agents.

Easy access to rapid transportation and displacement of people facilitate the spread of parasites and vectors among human populations worldwide. In addition, as a result of increased international travel and trade, local events acquire international importance. The human immunodeficiency virus (HIV) and the West Nile virus are recent examples in the field of infectious diseases.

Fidler (1996) emphasizes that biological agents travel by themselves or with their hosts and vectors without any recognition of, or regard for, political borders. He notes that with the continued expansion of economic trade across continents and more rapid transportation and travel, people infected with pathogens having short incubation periods can transmit diseases across several countries before becoming symptomatic. The protective effect of slow-moving clipper ship travel is thus a thing of the past.

Increased international trade has also aggravated the risk of cross-border transmission of infectious diseases. Globalization of food (and feed) trade, facilitated by liberalization of world trade, while offering many benefits and opportunities, also poses new risks. Food, a major trade commodity, is also an important vehicle for transmission of infectious diseases. Because food production, manufacturing, and marketing are now global, infectious agents can spread from the original point of processing and packaging to locations thousands of miles away (Käferstein et al., 1997).

Over the past 200 years, the average distance traveled and the speed of travel have increased 1,000-fold, while disease incubation periods have remained unchanged. As a result, a person can be exposed to a foodborne illness in one country and expose others to the infection thousands of miles from the source. Depending on their destination, travelers are estimated to run a 20 to $50 \%$ risk of contracting a foodborne illness.

Another disturbing phenomenon is the globalization of sexual exploitation and its consequences for health. Tourism is one of the most dynamic economic markets, even for underdeveloped nations. The expansion of transportation has led to the globalization of tourism, leading to one of the most profitable activities ever known. The World Tourism Organization (WTO) estimated world tourist arrivals at 567 million in 1995, and this figure was expected to reach 660 million by the year 2000 .

Many poor countries feature natural beauty and exoticism, attracting droves of tourists from wealthy countries, enticed by the laughable prices of tourism resulting from low local wages and devalued currency - an invariable prescription of the structural adjustment programs imposed by international agencies to stimulate foreign investment and reduce expenditure on imports.

However, in many of these Third World countries the globalized tourism industry is inseparable from the sexual exploitation of children, adolescents, and adults. Currently, many visitors to the world's tourist destinations come precisely because of opportunities for sexual exploitation. Such destinations include Brazil, the Caribbean, Thailand, Indonesia and several African countries. Quintanilla (1997) reports numerous examples of the globalization of sexual exploitation and its consequences for the dissemination of sexually transmitted diseases and mental and personal damage resulting from sexual abuse against children, adolescents, and women.

The sex trade often goes hand in hand with international organized crime, frequently related to drug and arms traffic. The national states, 
United Nations agencies, and several NGOs have played a significant role in exposing and controlling this heinous commerce that deeply affects health and represents one of the tragic and perverse aspects of economic inequalities.

Life styles and behavior patterns also spread quickly, rapidly becoming global and spawning the emergence and spread of non-communicable diseases.

Meanwhile, the process of organizing health services, including their ability to disseminate information and promote effective health education and vector control activities, spreads much more slowly because of economic, social, cultural, and organizational barriers.

The worldwide tendency towards urbanization and concentration of human populations in absurd spaces, often without minimum health conditions (or in radically unhealthy surroundings such as slums in large Third World cities), creates a favorable environment for the spread of pathogens, since human infectious and parasitic diseases can be transmitted from person to person or through vectors or fomites.

In many cases the technologies exist for prevention (vaccines and chemoprophylaxis) and/or treatment. Still, such resources are often unavailable to major population contingents or even to entire populations. Many countries cannot afford such health resources to make them available through adequate public health programs.

In international commerce, the World Trade Organization (WTO) invariably stands behind patent protection for health-related products. Most patents belong to private companies in developed countries. The case of antiretroviral drugs is illustrative. Antiretrovirals are known to improve survival and quality of life in HIV-infected individuals, but their high price impedes access by poor countries and by poor people inside wealthy countries.

The case of antiretrovirals sparked intense debate at the recent WTO meeting in Doha, Qatar. After widespread mobilization of countries and NGOs concerned with the consequences (for public health) of ironclad economic protectionist rules, the meeting generated a Declaration on the TRIPS Agreement and Public Health (WTO, 2001), an important victory for those defending public health vis-à-vis narrow economic criteria proposed by the WTO and some allied countries.

In this historical document defending a "virtuous globalization", member countries concurred that "the WTO Agreement on Trade-Related Aspects of Intellectual Property Rights (TRIPS Agreement) does not and should not pre- vent Members from taking measures to protect public health. Accordingly, while reiterating our commitment to the TRIPS Agreement, we affirm that the Agreement can and should be interpreted and implemented in a manner supportive of WTO Members' right to protect public health and, in particular, to promote access to medicines for all" (WTO, 2001).

The Declaration stated that "each Member has the right to grant compulsory licenses and the freedom to determine the grounds upon which such licenses are granted [and] has the right to determine what constitutes a national emergency or other circumstances of extreme urgency, it being understood that public health crises, including those relating to HIVIAIDS, tuberculosis, malaria and other epidemics, can represent a national emergency or other circumstances of extreme urgency". The document concludes by reaffirming "the commitment of developed-country Members to provide incentives to their enterprises and institutions to promote and encourage technology transfer to least-developed countries" (WTO, 2001).

Unfortunately we are dealing with a vicious, not virtuous rule: it is easier to globalize the financial crisis than health gains or access to diagnostic, preventive, and therapeutic technologies, even the simplest and most cost-effective, like vaccines.

\section{AIDS: an example of globalization of diseases}

According to the latest report by the Joint United Nations Program on HIV/AIDS (UNAIDS, 2001), over 60 million people have been infected by the AIDS virus since the beginning of the epidemic 20 years ago. Of these, 20 million have died, three million in 2001 alone. There are currently some 40 million people living with HIV. AIDS is already the fourth cause of death in the world, next to cardiovascular disease, violence (accidents and other violent causes), and cancer.

HIV continues to spread virtually unchecked in many regions of the world. According to the UNAIDS report, nearly five million people contracted HIV in 2001, of whom 3.4 million in Africa, more than half of whom are women. The most heavily affected region is still impoverished sub-Saharan Africa, where two-thirds of all cases (28 million) have occurred, and where AIDS is the first cause of death.

Still, the epidemic is spreading even faster in Eastern Europe and Central Asia. The largest increase in 2001 was in the former Soviet countries, with one million new cases. The main 
causes of this rapid increase in HIV infection are intravenous drug use, economic insecurity, high unemployment, and the deterioration of public health services.

The impact on many countries' economies is devastating. HIV mainly attacks individuals in their most productive years, and one-third of HIV-positive individuals are now 15 to 24 years old. The majority will not survive until the next decade, only because drugs are not accessible. Entire families have died, there are thousands of orphans, and agriculture, which is highly labor-intensive because of the almost non-existent technology, has began to collapse. In Africa, according to the report, "AIDS has become the biggest threat to the economic development of the continent".

International cooperation within the existing legislative mechanisms has, on occasion, been very successful. International eradication of smallpox was successful because a specific, cost-effective, efficient vaccine was developed; the disease attacked persons regardless of their economic, political, racial, religious, or social affiliations; the amount of funding was adequate; and all nations recognized the benefits of the eradication program. A similar effort currently in progress to eradicate poliomyelitis will also be successful because of international cooperation (Ginzburg, 1996).

In contrast, international control of other infectious diseases, such as malaria and tuberculosis, has been attempted for decades with considerably less success. Notwithstanding the lack of effective vaccines, the reality is that only very limited resources are being committed to prevent and treat all infectious diseases. Ebola virus and plague outbreaks are reported routinely, as occurred recently in the People's Republic of the Congo. However, the increasing incidence and prevalence of tuberculosis, AIDS, and other sexually transmitted diseases are accepted by many as problems of the poor, the immoral, and the expendable portions of society. Local, national, and international awareness and continued interest are significant issues.

International cooperation must extend beyond merely restricting the natural spread of specific diseases. The threat of infectious diseases as weapons provides an additional incentive for cooperation among governments. After the anthrax episode in the United States, the world recognizes the need for effective international treaties to prevent the use of biological agents in either tactical or strategic circumstances. Unfortunately, the recent news that the United States refused to sign the international agreement negotiated in Geneva to control bio- logical weapons has frustrated this international cooperation, postponing a possible agreement until late 2002.

Smallpox is the most serious threat in the area of bioterrorism. The disease was declared eradicated by the World Health Organization in 1980, after an extraordinary international public health campaign, including vaccination, education, etc.. The last case was reported in Somalia in 1977. Samples of the virus were kept in two laboratories in the superpowers: the CDC (Centers for Disease Control and Prevention) in Atlanta, United States, and the State Center for Virology and Biotechnology Research, near Novosibirski, Siberia, Russia.

No one is authorized to state (although there is a slight possibility) that a lethal and infectious sample of the smallpox virus has been smuggled to some country that could be inclined to use it as a biological weapon. However, it is true that it is much more difficult to culture and stabilize viruses than bacteria. After solving this technical problem, which is not simple, smallpox could in fact be used as a threat to the world. It would only require infecting some terrorists and moving them around the world. The virus would spread rapidly and we might have a pandemic, because all of the earth's six million inhabitants without exception are susceptible to contracting and developing the disease, since we all lack specific immunity to the smallpox virus. Children and the elderly would be the most affected.

Only a few countries in the world have the capability to produce smallpox vaccine. Brazil is one of them, and through the Oswaldo Cruz Foundation the country has begun preparations to produce approximately 35 million doses for the Ministry of Health's strategic reserve.

Some international efforts fostered by globalization should be seen as a sign of hope in cooperation and solidarity, both in the field of health and the economy.

Emerging infectious diseases and the growth of information technology have produced new demands and possibilities for disease surveillance and response. Increasing numbers of outbreak reports must be assessed rapidly so that control efforts can be initiated and unsubstantiated reports can be identified to protect countries from unnecessary economic damage. The World Health Organization has created a process for timely outbreak verification to convert large amounts of data into accurate information for suitable action.

To investigate and follow up on outbreak reports, WHO established an innovative mechanism known as outbreak verification in early 
1997. Outbreak verification is a new approach to global disease surveillance (Heymann \& Rodier, 1998). It aims to improve epidemic disease control by informing key public health professionals about confirmed and unconfirmed outbreaks of international public health importance.

Another source of hope, this time in the economic field, is the control of unfettered international speculative capital flows which have crushed national economies, through the Tobin tax, designed to levy on "hot money" to create a fund to stabilize stricken economies. The aim is to grant relief from debt service by the poorest countries, redirecting these resources to social projects. This proposal is also on the international agenda and deserves our full support.

Finally, it would be impossible to close without mentioning the extraordinary role that the National Institutes of Health (NIH)/Fogarty International Center have played (Keusch, 2001a, $2001 b$ ) in virtuous globalization, backing health research centers all over the world. This international cooperation provides solidarity for strengthening numerous institutions worldwide and for promoting important progress to deal with the main health problems still afflicting the global village.

\section{References}

FIDLER, D. P., 1996. Globalization, international law and emerging infectious diseases. Emerging Infectious Diseases, 2:77-82.

GINZBURG, H. M., 1996. Needed: Comprehensive response to spread of infectious diseases. Emerging Infectious Diseases, 2:151.

HEYMANN, D. L. \& RODIER, G. R., 1998. Global surveillance of communicable diseases. Emerging Infectious Diseases, 4:362-365.

HOBSBAWM, E., 1998. Era dos Extremos: O Breve Século XX, 1914-1991. São Paulo: Companhia das Letras.

LENDERBERG, J.; SHOPE, R. E. \& OAKS Jr., S. C. (ed.), 1992. Emerging Infection: Microbial Threats to Health. Washington, DC: Institute of Medicine.

KÄFERSTEIN, F. K.; MOTARJEMI, Y. \& BETTCHER, D. W., 1997. Foodborne disease control: A transnational challenge. Emerging Infectious Diseases, 3: 503-510.

KEUSCH, G. T., 2001a. Statement of the Director. 12 October 2001 <http://www.nih.gov/fic/about/ 2002open.html>.

KEUSCH, G. T., 2001b. Global Challenges in Health Disparity. 12 October 2001 <http://www1.od.nih. gov/ormh/conferences_meetings/keusch.html>.
PETTIFOR, A., 2000. Caminhos para um enfoque mais moderado da globalização. Observatório da Cidadania, 4:98-102.

QUINTANILLA, T., 1997. A globalização do comércio sexual. Observatório da Cidadania, 1:63-66.

UNAIDS (Joint United Nations Programme on HIV/ AIDS), 2001. AIDS Epidemic Update 2001. December 2001 <http://www.unaids.org/epidemic udate/report_dec01/index.html>.

WHO (World Health Organization), 1998. Global Financial Crisis Increases Risk of Deadly Child Infection, Children's Vaccine Initiative (CVI) Says. 19 October 2001 <http://www.who.int-pr-1998/en/ pr98-83.html>.

WORLD BANK, 2001. Globalization, Growth and Poverty: Building an Inclusive World Economy. Washington, DC: World Bank.

WTO (World Trade Organization), 2001. TRIPS Agreement. 23 November 2001 <http://www.wto.org/ english/thewto_e/minist_e/min01_e/mindecl_ tips_e.htm>.

Submitted on 1 April 2002

Approved on 4 June 2002 